\title{
Effects of complexation with in vivo enhancing monoclonal antibodies on activity of growth hormone in two responsive cell culture systems
}

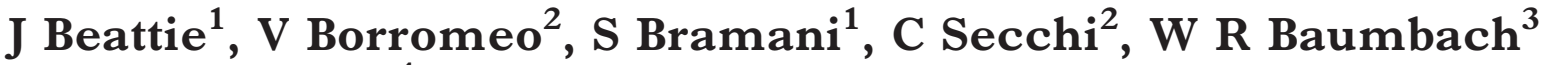 \\ and J Mockridge ${ }^{4}$ \\ ${ }^{1}$ Hannah Research Institute, Ayr KA6 5HL, UK \\ ${ }^{2}$ Department of Veterinary Medicine, University of Milan, Via Celoria 10, Milan, Italy \\ ${ }^{3}$ Molecular and Cellular Biology, American Cyanamid Company, Princeton, New Jersey, USA \\ ${ }^{4}$ Department of Cardiology, The Rayne Institute, UMDS, St Thomas's Hospital, Lambeth Palace Road, \\ London SE1 7EH, UK
}

(Requests for offprints should be addressed to J Beattie; Email: beattiej@hri.sari.ac.uk)

\begin{abstract}
We describe the properties of three monoclonal antibodies (MAbs) to ovine GH, two of which have previously been shown to enhance, in vivo, the biological activity of bovine and ovine growth hormone. We have examined the effects of these MAbs on GH activity in two appropriate GHresponsive cell culture systems, investigating both acute signalling effects (Janus-activated kinase (Jak)-2 tyrosine phosphorylation $-5 \mathrm{~min}$ ) and longer-term (MTT-formazan production $-24 \mathrm{~h}$ ) effects of hormone-antibody complexes. In the 3T3-F442A pre-adipocyte cell line (which has been demonstrated to be GH responsive), we show that complexation of recombinant bovine (rb) GH with either of the two enhancing anti-ovine GH MAbs (OA11 and OA15) and the non-enhancing MAb, OA14, attenuates the ability of GH to stimulate tyrosine phosphorylation of Jak-2 at a 5-min time point. Using the mouse myeloid cell line, FDC-P1,
\end{abstract}

stably transfected with the full-length ovine $\mathrm{GH}$ receptor (oGHR), we demonstrate that $\mathrm{rbGH}$ causes a dose-dependent increase in MTTformazan production by these cells. Further, we demonstrate that OA11 and OA14, but not OA15, cause a decrease in this stimulatory activity of $\mathrm{rbGH}$ over a hormone concentration range of $5-50 \mathrm{ng} / \mathrm{ml}$ at both 24 and $48 \mathrm{~h}$.

We conclude that the different in vitro activities of the two in vivo enhancing MAbs are most probably related to the time-courses over which these two assays are performed, and also to the relative affinities between antibody, hormone and receptor. In addition, the in vitro inhibitory activity of the enhancing MAb OA11 in both short- and long-term bioassay lends further support to an exclusively in vivo model for MAb-mediated enhancement of $\mathrm{GH}$ action.

Fournal of Molecular Endocrinology (1999) 23, 307-313

\section{INTRODUCTION}

The phenomenon of antibody-mediated enhancement of hormone activity has been extensively reported (Wallis et al. 1987, Holder et al. 1988, Holder 1992). Such observations have been made principally with the pituitary growth hormone (GH) and have almost exclusively examined activity in vivo in the GH-deficient Snell dwarf mouse. Although several theories have been advanced to explain this enhancing effect in vivo (Massart et al. 1993, van der Hel et al. 1994, Tans et al. 1994), there are few data available that describe the activity of these antibodies in suitable GH-responsive cell culture models. Using the GH-responsive mouse pre-adipocyte cell line 3T3-F442A, we have recently demonstrated that the in vivo enhancing monoclonal antibody (MAb), OA15, allows for the interaction between $\mathrm{GH}$ and receptor (such that the tripartite complex MAb-hormone-receptor is formed), but appears to attenuate Janus-activated kinsase (Jak)-2 tyrosine phosphorylation in response to recombinant bovine (rb) GH in these cells (Beattie et al. 1999). We rationalised such receptor 
and biological activity on the previously described epitope defined by this enhancing antibody, which was removed from both sites 1 and 2 on the GH molecule, which are important for receptor interaction. We have now extended these studies with another GH-enhancing MAb (OA11) and have also examined the effects on rbGH activity of $\mathrm{MAb}$ OA14, which does not enhance in vivo the activity of ovine (o) GH. In addition to the 3T3-F442A pre-adipocyte cell culture system, we have examined the effect on longer-term (24-48 h) GH activity using the mouse promyeloid cell line, FDC-P1, transfected with the full-length oGH receptor (oGHR) and MTT-formazan dye production as an endpoint. We present results of experiments that report the effect of complexation of rbGH with each of these three MAbs on subsequent hormone activity in these two experimental models.

\section{MATERIALS AND METHODS}

\section{Materials}

Tissue culture plastic was from CoStar (Dursley, Glos, UK). Culture media (including phenol-redfree RPMI 1640), newborn and foetal calf serum and antibiotics were from Gibco (Inchinnan, Scotland). Mini-gel and blotting apparatus was from Bio-Rad (Herts, UK). rbGH (rbGHMet $^{1} . .$. Leu $^{127}$, lot No. M-118-08308) was a gift from Dr R Collier (Monsanto Corp, St Louis, MO, USA). oGH (oGH-I-4), rat GH (rGH-I-6), rat prolactin (PRL; ratPRL-I-5) and oPRL (oPRLI-3) were from NIDDK (Bethesda, MD, USA). Porcine (p) GH (pGH-B-1) and pPRL (pPRL-B-1) were from the United States Department of Agriculture. Polyclonal rabbit anti-mouse Jak-2 and the monoclonal anti-phosphotyrosine antibody 4G10 were both from Upstate Biotechnology (New York, NY, USA). Horseradish peroxidase (HRP)conjugated secondary antibodies were from Sigma (Poole, Dorset, UK). Pansorbin (killed suspension of Staphylococcus aureas) was from Calbiochem (product No. 507861). Enhanced chemiluminescent (ECL) reagent and ECL Hyperfilm were from Amersham (Amersham, Bucks, England). Monoclonal antibodies OA11, OA14 and OA15 were raised to oGH and were used as dialysed $18 \%$ $(\mathrm{NH} 4)_{2} \mathrm{SO}_{4}$ fractions of hybridoma supernatants. Protein concentrations were approximately $0.6 \mathrm{mg} /$ $\mathrm{ml}$. These antibodies have been partially characterised previously (Aston et al. 1987). The mouse preadipocyte cell line, 3T3-F442A (Green \& Kehinde 1976) was supplied by Dr Howard Green (Harvard Medical School, Boston, MA, USA). The mouse myeloid cell line, FDC-P1 (Hapel et al. 1984), stably transfected with the full-length oGHR, oGHR-FDC$\mathrm{P} 1$, was propagated as described in the Methods section. MTT reagent (3-(4,5-dimethyl thiazol-2yl)2,5-diphenyl tetrazolium bromide), ABTS $\left(2,2^{\prime}\right.$ azino-bis(3-ethylbenzthiazoline-6-sulphonic acid) and mouse interleukin-3 (mIL-3) were from Sigma.

\section{Methods}

\section{Cell culture}

3T3-F442A cells were propagated as described previously (Beattie et al. 1999). FDC-P1 cells stably expressing full-length oGHR grow in suspension and were maintained in RPMI 1640 containing $50 \mathrm{U} / \mathrm{ml}$ penicillin-streptomycin, $10 \%$ fetal calf serum (FCS), $2 \mathrm{mM}$ glutamine and $50 \mathrm{U} / \mathrm{ml}$ recombinant mIL-3 (Sigma). Cells were grown in $225 \mathrm{~cm}^{2}$ flasks and were split $(1: 10)$ when they reached a density of $1-2 \times 10^{6}$ per ml.

\section{Stimulation of oGHR-transfected FDC-P1 cells}

Stimulation of oGHR-FDCP1 cells was assessed using the MTT-formazan dye assay (Mosmann 1983). Cells were grown in complete medium as described above, washed by centrifugation at $500 \times \boldsymbol{g}$ for $5 \mathrm{~min}$ and resuspended in the RPMI 1640. Washed cells were resuspended at a density of $8 \times 10^{5}$ cells per $\mathrm{ml}$ in RPMI $1640-0 \cdot 5 \%$ FCS. Fifty microlitres of this cell suspension were dispensed into a 96-well microtitre plate $(40000$ cells per well), followed by $100 \mu$ hormone solution appropriately diluted in RPMI $1640-0 \cdot 5 \%$ FCS. After incubation (3-72 h), $20 \mu \mathrm{l} \mathrm{MTT}$ at a concentration of $0.5 \mathrm{mg} / \mathrm{ml}$ in RPMI 1640 was added to each well, and after a further $3 \mathrm{~h}$ of incubation, cells were lysed with $150 \mu \mathrm{l} 0 \cdot 12 \mathrm{M} \mathrm{HCl}$ in isopropyl alcohol. The contents of microtitre wells were resuspended thoroughly by trituration and absorbance in each well was determined at $540 \mathrm{~nm}$. In experiments that examined the effect of antibody complexation on the subsequent response to $\mathrm{rbGH}$, hormone was incubated at concentrations of $1-50 \mathrm{ng} / \mathrm{ml}$ with MAbs at a dilution of $1: 100$. MAb and hormone were incubated at room temperature for $1 \mathrm{~h}$ before addition to cells. All hormone and hormone/ antibody treatments were applied in triplicate and results are presented as means \pm s.E.

\section{ELISA}

High-binding Immulon-2 microtitre plates were coated with $0 \cdot 5 \mu \mathrm{g} /$ well $\mathrm{rbGH}$ in $50 \mathrm{mM} \mathrm{NaHCO}$ (pH 9.6). One hundred microlitres serial MAb dilutions in $50 \mathrm{mM}$ Tris, $150 \mathrm{mM} \mathrm{NaCl}, 0 \cdot 2 \%$ Tween 20, pH $8 \cdot 0$ ('TBS-T) were incubated with microtitre plates for $2 \mathrm{~h}$ at $22{ }^{\circ} \mathrm{C}$. Plates were then 
washed in TBS-T and incubated for $2 \mathrm{~h}$ with anti-mouse-HRP conjugate (diluted 1:1000 in TBS-T). After the plates were further washed in TBS-T, colour was developed by the addition of $100 \mu \mathrm{l} /$ well $0.5 \mathrm{mg} / \mathrm{ml} \mathrm{ABTS}$ in $0.1 \mathrm{M}$ phosphatecitrate buffer ( $\mathrm{pH} 4$ ), $0.01 \%$ (v:v) $\mathrm{H}_{2} \mathrm{O}_{2}$. After $30 \mathrm{~min}$ further incubation of the plates, absorbance was determined at $405 \mathrm{~nm}$.

\section{GH stimulation of Fak-2 tyrosine phosphorylation}

$\mathrm{GH}$ stimulation of tyrosine phosphorylation of Jak-2 in monolayer cultures of 3T3-F442A cells was performed as described by Argetsinger et al. (1993). Effects of MAb complexation of $\mathrm{GH}$ on subsequent Jak-2 tyrosine phosphorylation was performed exactly as described previously (Beattie et al. 1999).

Receptor binding studies in transfected FDC-P1 cells oGHR-transfected FDC-P1 cells $\left(10^{7}\right.$ per tube $)$ were incubated overnight at $4{ }^{\circ} \mathrm{C}$ with $10^{6}$ c.p.m. ${ }^{125} \mathrm{I}-\mathrm{rbGH}$ in a total volume of $300 \mu \mathrm{l}$ binding buffer (10 mM Tris.Cl (pH 7.4), $10 \mathrm{mM} \mathrm{CaCl}, 0 \cdot 1 \%$ BSA). After centrifugation (1800 $\boldsymbol{g}$ for $30 \mathrm{~min}$ ), supernatants were decanted and bound radioactivity in the pellet was determined. Non-specific binding was assessed in the presence of $1 \mu \mathrm{g}$ unlabelled rbGH and typically accounted for $3-4 \%$ of added c.p.m. Scatchard analysis was achieved by quantitation of ${ }^{125} \mathrm{I}-\mathrm{rbGH}$ bound to cells in the presence of increasing concentrations of unlabelled rbGH.

\section{RESULTS}

In Fig. 1, we present the results of experiments that characterise in detail the response of the oGHRFDC-P1-transfected cells to added hormones. We monitored the production of MTT-formazan as a result of $\mathrm{GH}$ treatment and it is important to note that this assay monitors the stimulation of both metabolic and mitogenic activity in these cells. In Fig. 1a, cells are shown to respond dose dependently to $\mathrm{rbGH}$ with an $\mathrm{EC}_{50}$ of approximately $2.5 \mathrm{ng} / \mathrm{ml}$. When we examined the specificity of the response of oGHR-FDCP1 cells to various species of $\mathrm{GH}$, we observed the reactivity profile shown in Fig. 1b. In our hands, rbGH demonstrated a greater activity than the pituitary-derived oGH preparation that was available in our laboratory and, indeed, earlier studies have reported that bovine $\mathrm{GH}$ is active in vivo in sheep (Bass et al. 1991, Sauerwein et al. 1991). Porcine and rat GH displayed equivalent reactivities that were lower than that seen for the ruminant GH (Fig. 1b). As expected, none of the PRLs tested (o, r, p, or $\mathrm{m}$ ) demonstrated activity in these cells (Fig. 1c). The time-course of hormone stimulation with 10,100 and $1000 \mathrm{ng} / \mathrm{ml}$ rbGH showed an effect of hormone $6 \mathrm{~h}$ after its addition, with the stimulatory effect of $\mathrm{GH}$ continuing to increase up to $72 \mathrm{~h}$ after the addition of rbGH (Fig. 1d). Scatchard analysis of rbGH binding to oGHR-FDCP1 cells indicated a $K_{\mathrm{d}}$ of $1 \times 10^{-9} \mathrm{M}$ for hormone-receptor binding, similar to previously reported values for the GH-GHR interaction. Estimation of total binding sites revealed 2200 per cell (Fig. 2).

Having clearly characterised the specificity of response of this stably transfected cell line to rbGH, we were able to undertake experiments that investigated the effects of three MAbs to oGH (OA11, OA14 and OA15) on the in vitro biological activity of rbGH. Two of these antibodies, OA11 and OA15, have been shown to enhance the activity of oGH when they are precomplexed with hormone and administered to hypopituitary Snell dwarf mice. Precomplexation of oGH with MAb OA14 did not enhance the activity of hormone (Aston et al. 1987). Initial characterisation of MAbs by ELISA indicated that they exhibited similar titres against rbGH (data not shown) and we therefore examined their activity at the same dilution over a range of rbGH concentrations. When used at final dilutions of $1: 100$, OA11 and OA14, but not OA15, inhibited the activity of rbGH in this bioassay (Fig. 3). For $\mathrm{MAb}$ OA11, inhibition of rbGH activity was evident over the entire range of hormone concentrations at a $24 \mathrm{~h}$ time point. For OA14, inhibition was overcome at the highest concentration of $\mathrm{rbGH}$ examined $(50 \mathrm{ng} / \mathrm{ml})$. Similar results were obtained at $48 \mathrm{~h}$ (data not shown).

In a separate in vitro bioassay system using the GH-responsive pre-adipocyte cell line, 3T3-F442A, OA11 and OA14-again at a final dilution of 1:100 - appeared to attenuate the level of tyrosine phosphorylation of the tyrosine kinase Jak-2 caused by treatment of cells with $50 \mathrm{ng} / \mathrm{ml} \mathrm{rbGH}$ for $5 \mathrm{~min}$ (Fig. 4). We have demonstrated previously that OA15 at the same dilution also attenuates GHstimulated Jak-2 tyrosine phosphorylation (Beattie et al. 1999).

\section{DISCUSSION}

In the current study, we have clearly shown that the FDC-P1 cell line transfected with full-length oGHR responds specifically to ruminant GHs. Although there are no other published data on FDC-P1 cells transfected with ruminant GHRs, Fiddes et al. (1992) reported the functional expression of full-length oGHR in transfected Chinese hamster ovary $(\mathrm{CHO})$ cells. The reported 

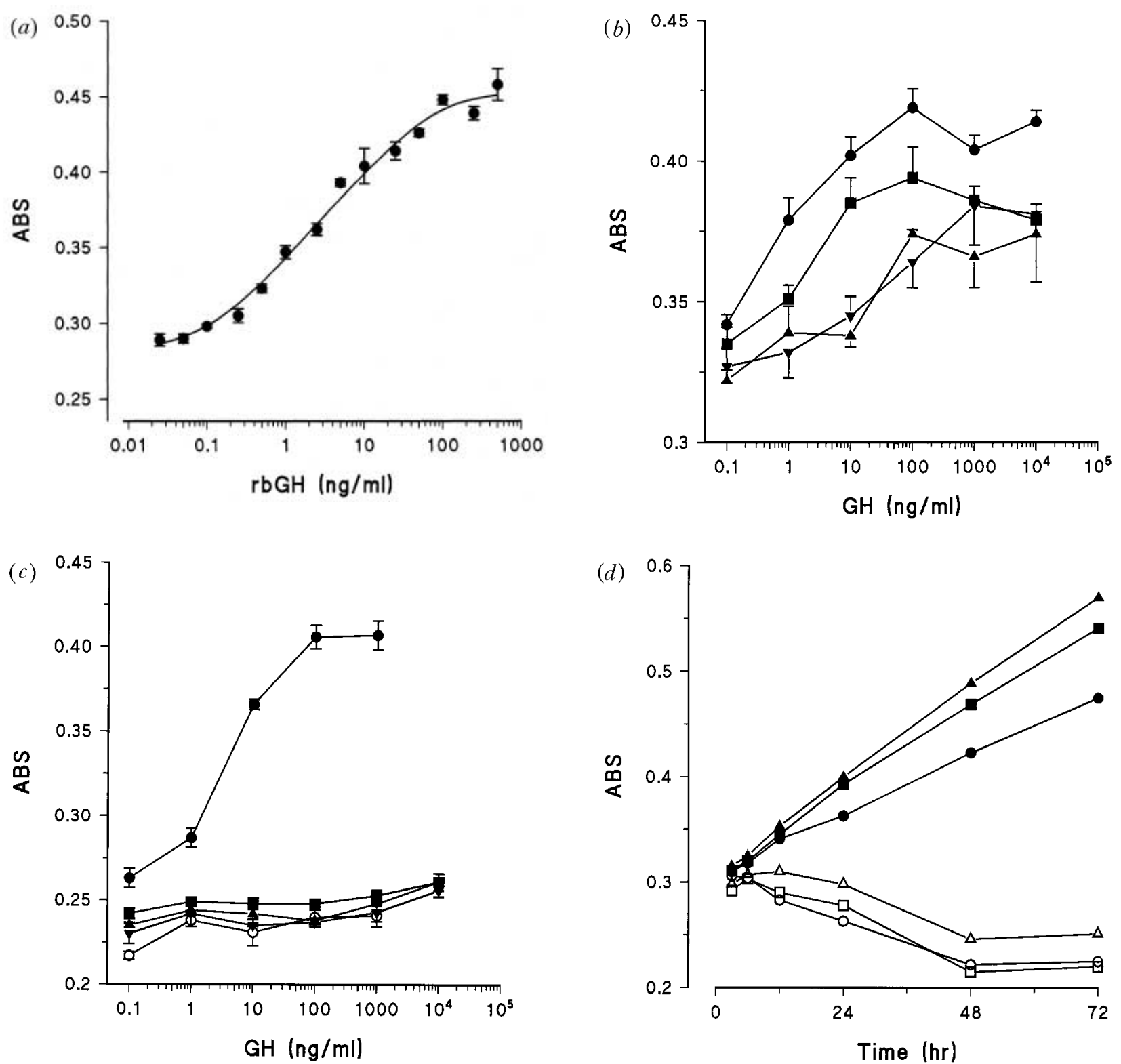

FIGURE 1. (a) The response of oGHR-FDC-P1-transfected cells to increasing concentrations of rbGH. Cells were treated for $24 \mathrm{~h}$ with $\mathrm{rbGH}$ as described in Methods section. MTT assay revealed a dose-dependent effect of rbGH with an $\mathrm{EC}_{50}$ of approximately $2.5 \mathrm{ng} / \mathrm{ml}$. Mean \pm s.E. $(n=3)$ for each hormone concentration. (b) Specificity of response of oGHR-transfected FDC-P1 cells to various species of GH. Cells were treated for $24 \mathrm{~h}$ with increasing concentrations $(0 \cdot 1-10000 \mathrm{ng} / \mathrm{ml})$ of $\mathrm{rb}(\boldsymbol{O})$, ovine $(\boldsymbol{\square})$, porcine $(\boldsymbol{\Delta})$, or rat $(\boldsymbol{\nabla}) \mathrm{GH}$. Mean \pm s.E. $(n=3)$ for each hormone and concentration. (c) oGHR-transfected cells do not respond to PRL. Cells were treated for $24 \mathrm{~h}$ with $\operatorname{rbGH}(\boldsymbol{O} ; 0 \cdot 1-1000 \mathrm{ng} / \mathrm{ml})$ or with ovine $(\boldsymbol{\square})$, rat $(\boldsymbol{\Delta})$, mouse $(\bigcirc)$ or porcine $(\boldsymbol{\nabla})$ PRL. Mean \pm s.E. $(n=3)$ for each hormone and treatment. $(d)$ Time-course of stimulation of oGHR-transfected FDC-P1 cells with rbGH. Cells were treated with $0(\bigcirc), 0 \cdot 1(\square), 1(\triangle), 10(\mathbf{O}), 100(\boldsymbol{\square})$ or $1000(\boldsymbol{\Delta}) \mathrm{ng} / \mathrm{ml} \mathrm{rbGH}$ and over the period 3-72 h. ABS, absorbance at $405 \mathrm{~nm}$.

affinity of oGHR in their study, at $0 \cdot 3 \mathrm{nM}$, was similar to that found in the current investigation. However, at 220000 receptors per cell, the level of expression was of the order of 100 -fold greater than that in our experiments with FDC-P1 cells. Using increases in cellular protein synthesis as a measure 


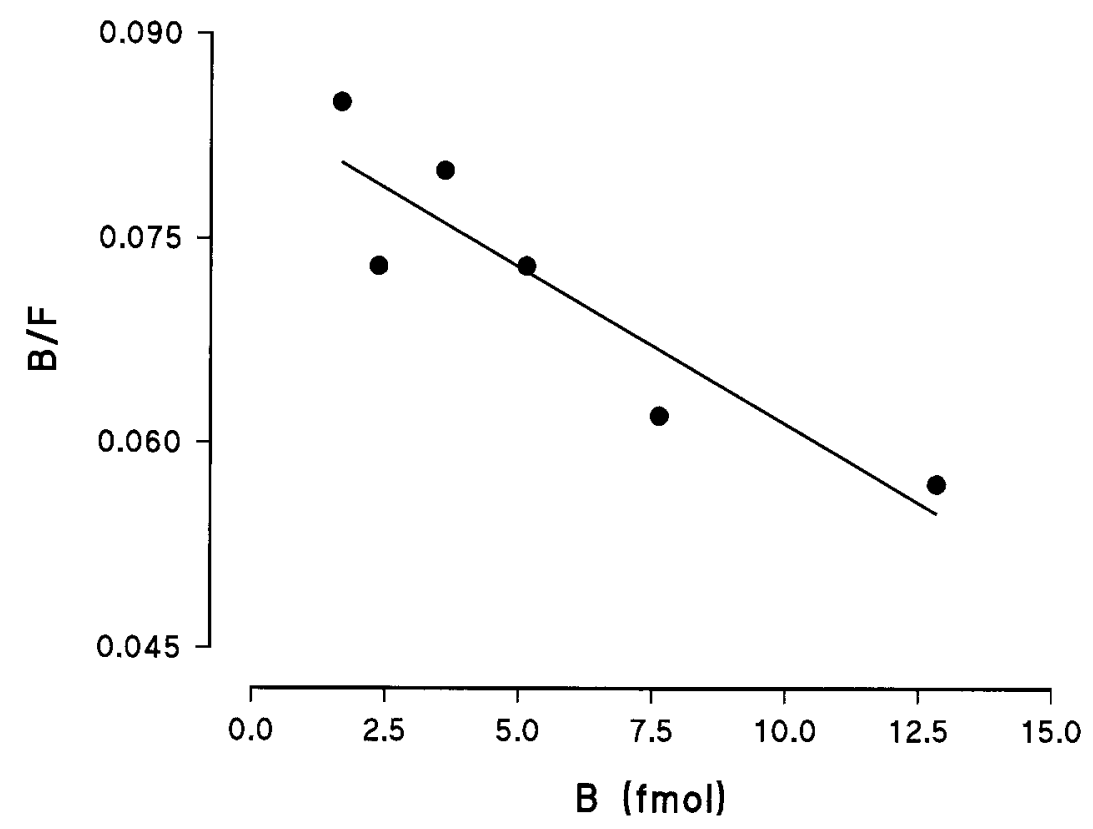

FIGURE 2. Scatchard analysis of rbGH binding to oGHR-FDC-P1 cells. Linear regression analysis gave a regression line represented by the equation $y=-0 \cdot 0023 x+0 \cdot 0844\left(r^{2}=0 \cdot 82\right)$ estimating $K_{\mathrm{d}}$ at $1.4 \mathrm{nM}$ and approximately 2200 binding sites per cell. For further details see Methods section.

$\mathrm{B}$, bound; $\mathrm{F}$, free.

of $\mathrm{GH}$ activity, these authors reported a $27 \%$ increase in this parameter after GH treatment. They also reported that the GH-related hormone, ovine placental lactogen, was active in the oGHRtransfected CHO cells. We did not test the activity of this hormone in our transfected FDC-P1 cell line; however, there is preliminary evidence that, although not active on its own, it inhibits the activity of simultaneously added oGH (data not shown).

No studies have been reported on FDC-P1 cells transfected with the oGHR, but it is important to note that other species of GHR have been transfected into this cell line, either as full-length GHR proteins or as chimeric molecules containing the extracellular domain of the GHR linked to the cytosolic portion of the granulocyte-colony stimulating factor receptor (Fuh et al. 1992, Hackett et al. 1995, 1997, Rowlinson et al. 1995, 1998, Wang et al. 1995). Rowlinson et al. (1995), for example, described FDC-P1 cells stably expressing fulllength human rabbit or rat GHR. When these cells were maintained in IL-3 containing (GH free) medium, as for the current study, they expressed a very similar number of receptors per cell (approximately 2100 and 2400, for the human GHR and rabbit GHR, respectively). When they examined

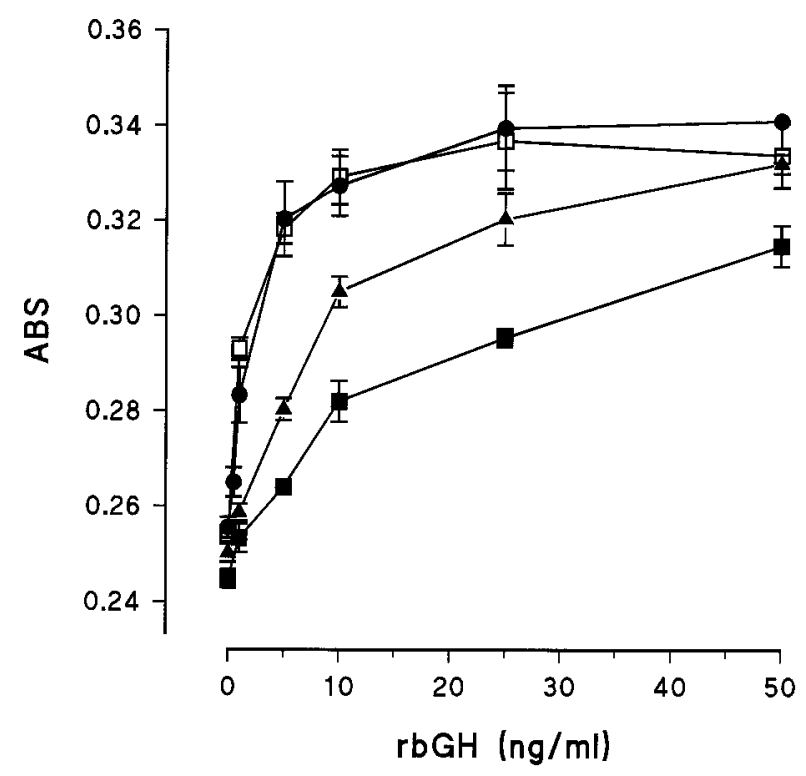

FIGURE 3. Effect of pre-incubation with MAbs on activity of rbGH. Varying doses of $\mathrm{rbGH}(0-50 \mathrm{ng} / \mathrm{ml})$ were incubated for $1 \mathrm{~h}$ with OA11 $(\boldsymbol{\square})$, OA14 $(\boldsymbol{\Delta})$ or OA15 $(\square)$ at a final dilution of $1: 100$ before addition to cells. Activities are compared with that seen for free rbGH ( ) over the same concentration range.

Incubations were for 24 h. Mean \pm S.E. $(n=3)$. ABS, absorbance at $405 \mathrm{~nm}$.

Fournal of Molecular Endocrinology (1999) 23, 307-313 


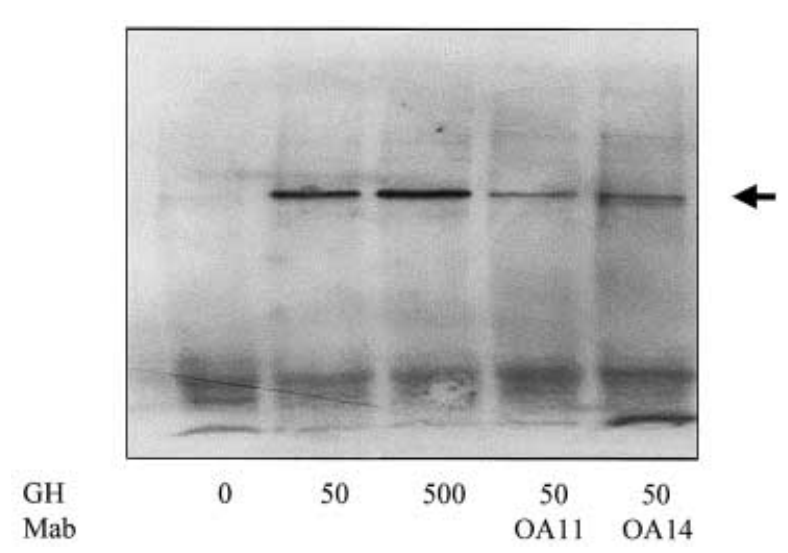

FIGURE 4. Effect of precomplexation of $\mathrm{rbGH}$ with MAbs OA11 and OA14 on GH-stimulated Jak-2 tyrosine phosphorylation in $3 \mathrm{~T} 3-\mathrm{F} 442 \mathrm{~A}$ pre-adipocytes. Cells were treated with 0,50 or $500 \mathrm{ng} / \mathrm{ml} \mathrm{rbGH}$ or with $50 \mathrm{ng} / \mathrm{ml} \mathrm{rbGH}$ precomplexed with OA11 or OA14 as indicated in the figure. The location of tyrosinephosphorylated Jak-2 is indicated by the arrow. This experiment was repeated three times with similar results in each instance. See Methods section for further details.

the activity of porcine, bovine and human GH on cells expressing full length rabbit GHR, using either thymidine incorporation or MTT assay, they reported that bovine and human GH had a threefold greater biopotency than the porcine molecule. As expected in our study, with the oGHR transfected cells we found $\mathrm{rbGH}$ to be more active than $\mathrm{pGH}$ at the ruminant receptor (Fig. 1B). In the study reported by Rowlinson et al. (1995) and in other studies (Fuh et al. 1992) using a similar in vitro bioassay system, a characteristic bell-shaped doseresponse curve was observed, with a decrease in biological activity of hormone apparent at greater concentrations. This has, typically, been interpreted in the context of a productive $1: 2$ stoichiometry between GH and GHR, with high concentrations of $\mathrm{GH}$ driving the formation of non-biologically productive $1: 1$ ligand-receptor complexes. In our experiments, we observed a plateau of activity for $\mathrm{rbGH}$ and oGH at around $100 \mathrm{ng} / \mathrm{ml}$ of hormone and evidence for slight decreases in activity as the concentrations were increased to $10000 \mathrm{ng} / \mathrm{ml}$. The less active $\mathrm{pGH}$ and $\mathrm{rGH}$ showed little evidence for this bell-shaped activity-perhaps indicative of a failure to meet maximum potential biological activity by these hormones.

It is interesting to compare the results obtained after complexation of rbGH with the two in vivo enhancing monoclonal antibodies in both cell culture systems. OA11 inhibits hormone activity both in oGHR-FDC-P1 cells and in the
3T3-F442A pre-adipocytes. Our experiments in 3T3-F442A cells were carried out with a fixed concentration of $\mathrm{rbGH}-50 \mathrm{ng} / \mathrm{ml}$. At this concentration of hormone, the inhibitory effects of OA11 are partially overcome in the oGHR-FDC-P1 cells in the MTT assay. It is important to note, however, that this assay takes place over a $24-\mathrm{h}$ period, and we believe that dissociation of hormone from MAb under these tissue-culture conditions may allow activity at the GHR. Indeed, such an equilibrium of hormone between receptor and MAb is favoured by reported affinity constants for MAb-hormone interaction of the order of $10^{-8} \mathrm{M}$ (Aston et al. 1987), placing them at least one order of magnitude below the affinity of the GH-GHR interaction. GH stimulation of Jak-2 tyrosine phosphorylation in 3T3-F442A cells, however, is an acute event, and our incubations operate over a 5-10 min timescale. Kinetically, therefore, we believe that, under these conditions, the majority of hormone remains bound to $\mathrm{MAb}$ and results in attenuation of $\mathrm{GH}$ activity. In addition, affinity of $\mathrm{rbGH}$ for the mGHR, as presented by the 3T3-F442A cells, may be less than rbGH affinity for the largely homologous ruminant oGHR in the transfected FDC-P1 cells, again favouring inhibition of $\mathrm{GH}$ activity in the pre-adipocyte cell line.

For the other in vivo enhancing MAb, OA15, contradictory results seem to be apparent. This $\mathrm{MAb}$ does not appear to inhibit rbGH activity in the oGHR-FDC-P1 cell line, in which the activity profile of OA15-rbGH complexes was almost superimposable on that seen with rbGH alone. This can be rationalised with our previous demonstration that the epitope on rbGH defined by this MAb is removed from both the sites on $\mathrm{GH}$ responsible for GHR interaction (Beattie \& Holder 1994) and, indeed, cell-based receptor assays and biosensor studies have confirmed that $\mathrm{GH}$ complexed with OA15 is still able to bind the extracellular domain of the ruminant GH receptor (Beattie et al. 1999). The results of the experiment described in Fig. 3 suggests that OA15-rbGH complexes are fully active. However, in our previous experiments with this antibody in 3T3-F442A cells, we have shown that (similar to OA11 and OA14 complexation) precomplexation of rbGH with OA15 attenuated the ability of the hormone to activate Jak-2. Although difficult to rationalise at present, it is clear that OA15 complexation with rbGH somehow affects the ability of hormone to activate GHR in the pre-adipocyte cell line, but not the oGHR-FDC-P1 cells. This may be related to receptor numbers per cell, or to some other differences in the spatial relationship between MAbGH-GHR complexes in the two assay systems. Experiments in oGHR-FDC-P1 cells are currently 
in progress to correlate the effect of MAb complexation on GH activity, as determined by 24-h MTT assay, with effects on short-term GH-stimulated signalling events.

\section{REFERENCES}

Argetsinger LS, Campbell GS, Yang X, Witthun BA, Silvennoinen O, Ihle JN \& Carter-Su C 1993 Identification of JAK2 as a growth hormone receptor associated tyrosine kinase. Cell 74 237-244.

Aston R, Holder AT, Ivanyi J \& Bomford R 1987 Enhancement of bovine growth hormone activity in vivo by monoclonal antibodies. Molecular Immunology 24 143-150.

Bass JJ, Oldham JM, Hodgkinson SC, Fowke PJ, Sauerwein H, Molan P, Breier BH \& Gluckman PD 1991 Influence of nutrition and bovine growth hormone $(\mathrm{GH})$ on hepatic $\mathrm{GH}$ binding, insulin-like growth factor-I and growth of lambs. Fournal of Endocrinology 128 181-186.

Beattie J \& Holder AT 1994 Location of an epitope defined by an enhancing monoclonal antibody to growth hormone: some structural details and biological implications. Molecular Endocrinology 8 1103-1110.

Beattie J, Bramani S, Secchi C \& Mockridge J 1999 Binding and signalling properties of a growth hormone enhancing monoclonal antibody. Molecular and Cellular Biochemistry (In Press).

Fiddes RJ, Brandon MR \& Adams TE 1992 Functional expression of an ovine growth hormone receptor in transfected Chinese hamster ovary cells, Molecular and Cellular Endocrinology 86 37-47.

Fuh G, Cunningham BC, Fukunaga R, Nagata S, Goeddel DV \& Wells JA 1992 Rational design of potent antagonists to the human growth hormone receptor. Science $2561677-$ 1680 .

Green H \& Kehinde O 1976 Spontaneous and heritable changes leading to increased adipose conversion in $3 \mathrm{~T} 3$ cells. Cell 7 105-113.

Hackett RH, Wang Y-D \& Larner AC 1995 Mapping of the cytoplasmic domain of the human growth hormone receptor required for the activation of Jak2 and Stat proteins. Fournal of Biological Chemistry 270 21326-21330.

Hackett RH, Wang Y-D, Sweitzer S, Feldman G, Wood WI \& Larner AC 1997 Mapping of a cytoplasmic domain of the human growth hormone receptor that regulates rates of inactivation of Jak2 and Stat proteins. Fournal of Biological Chemistry 272 11128-11132.

Hapel AJ, Warren HS \& Hume DA 1984 Different colonystimulating factors are detected by the interleukin3'-dependent cell lines FDC-Pl and 32D cl-23. Blood 64 786-790
Hauser SD, McGrath MF, Collier RJ \& Krivi GG 1990 Cloning and in vivo expression of bovine growth hormone receptor mRNA. Molecular and Cellular Endocrinology $\mathbf{7 2}$ $187-200$.

van der Hel W, Parmentier HK, Hole NJK, James S, Brandsma HA, Fentener van Vlissingen JM, Nieuwland MGB \& Joling P 1994 Effect of recombinant porcine somatotropin and monoclonal antibody directed to ovine somatotrophic hormone on nitrogen retention and immune parameters in pigs. Fournal of Animal Science 72 2820-2827.

Holder AT 1992 GH antibodies and somatic growth. In Regulation of Growth Hormone and Somatic Growth, pp 363-398. Ed De La Cruz. Excerpta Medica International Congress Series 996. Amsterdam: Elsevier.

Holder AT, Blows JA, Aston R \& Bates PC 1988 Monoclonal antibody enhancement of the effects of human growth hormone on growth and body composition in mice. Fournal of Endocrinology 117 85-90.

Massart S, Maiter D, Portetelle D, Adam E, Renaville R \& Ketelslegers J-M 1993 Monoclonal antibodies to bovine growth hormone potentiate hormonal activity in vivo by enhancing growth hormone binding to hepatic somatogenic receptors. Fournal of Endocrinology 139 383-393.

Mosmann T 1983 Rapid colourimetric assay for cellular growth and survival: application to proliferation and cytotoxicity assays. Fournal of Immunological Methods 65 55-63.

Rowlinson SW, Barnard R, Bastiras S, Robins AJ, Brinkworth R \& Waters MJ 1995 A growth hormone agonist produced by targeted mutagenesis at binding site 1 . Fournal of Biological Chemistry 270 16833-16839.

Rowlinson SW, Behncken SN, Rowland JE, Clarkson RW, Strasburger CJ, Wu Z, Baumbach W \& Waters MJ 1998 Activation of chimeric and full-length growth hormone receptors by growth hormone receptor monoclonal antibodies. Fournal of Biological Chemistry 273 5307-5314.

Sauerwein H, Breier BH, Bass JJ \& Gluckman PD 1991 Chronic treatment with bovine growth hormone upregulates high affinity hepatic somatotropic receptors in sheep. Acta Endocrinologica 124 307-313.

Tans C, Dubois F, Zhi-Duan Z, Jadot M, Wattiaux R, Wattiaux-De \& Coninck S 1994 Uptake by rat liver of bovine growth hormone free or bound to a monoclonal antibody. Biology of the Cell 82 45-49.

Wallis M, Daniels M, Ray KP, Collingham JD \& Aston R 1987 Monoclonal antibodies to bovine growth hormone potentiate the effects of the hormone on somatomedin-C levels and growth of hypophysectomised rats. Biochemical and Biophysical Research Communications 149 187-193.

Wang Y-D, Wong K \& Wood WI 1995 Intracellular tyrosine residues of the human growth hormone receptor are not required for the signalling of proliferation or Jak-STAT activation. Fournal of Biological Chemistry 270 7021-7024.

REVISED MANUSCRIPT RECEIVED 1 July 1999 